\title{
Determining value co-creation opportunity in B2B services
}

\author{
Karuna P Joshi \\ CSEE Department \\ University of Maryland, Baltimore County \\ Baltimore, MD, USA \\ kjoshi1@umbc.edu
}

\author{
Murthy Chebbiyam \\ IBM \\ IBM Research \\ New Delhi, India \\ mchebiyy@in.ibm.com
}

\begin{abstract}
In Business to Business (B2B) IT outsourcing contracts service providers have to demonstrate value continuously to retain client loyalty. However, sustained value can only be co-created by both service providers and clients though a collaborative process. This process of jointly creating value is termed value co-creation. In this paper we present a new technique that we have devised to identify the opportunities for value co-creation based on priorities for value drivers in an IT enabled B2B services contract. We illustrate this technique by applying it to the IT Helpdesk service.
\end{abstract}

Keywords- services; value co-creation

\section{INTRODUCTION}

Business to Business (B2B) outsourcing of IT Enabled Services (ITeS) has significantly matured over the last decade. While services providers have improved their capabilities through several innovative approaches like operational excellence, delivery excellence, quality improvement program, etc.; a wide gap still exists in the outcome value derived by clients from these relationships. The service providers also face challenges in realizing continuous value from the existing contracts due to competition and market conditions. Managing client relationships in a way that creates unique value for the client has become one "organizational capability" [19] by which organizations can create sustained competitive advantage. The supplier who can maximize value creation for the client is most likely to be successful in keeping the business. Also with rising resistance to business process outsourcing, IT service providers are increasingly focused on retaining and strengthening their client relationships. In the same way, clients are concerned with strategic sourcing and categorization of their supplier relationships.

In an outsourcing contract, the client typically expects value from service provider after the relationship matures. The perception of value begins only at a certain relationship maturity stage when the value opportunity is provided by the client. Until then the value from view point of provider does not translate to acknowledged client value; rather translates to better quality of service and informal value acknowledgement [13]. Under these conditions, there is a limited understanding of the mutual organizational processes, competencies, and which drivers are crucial for how value is co-created jointly by the parties. According to traditional business practices it is risky for both supplier and client organization to engage in cooperation because of difference in priorities to manage the contract.
Co-creation is a value creation process in which suppliers and clients engage in interactions to exchange knowledge and resources in order to co-create value [2][7]. Co-creation involves numerous interactions and can be thought of as value cycles rather than Porter's traditional linear value chain concept [5]. Prahalad and Ramaswamy [7] state that "the use of interaction as a basis for co-creation is at the crux of our emerging reality." As the client organization participation becomes the center of value creation, both stakeholders (i.e. the client and service provider) need to understand the process of co-creation. The process of value co-creation can be described in four key building blocks; dialogue, access, risk assessment and transparency [7]. Service providers are the interested players in this game of value co-creation and want to exploit the opportunity more in $\mathrm{B} 2 \mathrm{~B}$ relations. The real challenge is to convince clients to actively participate. Some professional service firms have established formal initiatives to educate their clients on the value of servicing a knowledgeable client [14].

While there has been some work done on value co- creation in services, no one has attempted to quantify the process of value co-creation by the service provider and client on the basis of their priorities and the parameters or value drivers it depends on. In this paper we propose a technique to identify the value co-creation opportunity in service delivery by prioritizing the value drivers. This technique helps to identify the expected value based on priorities and determine which drivers of value should the two parties concentrate on to improve the overall value in the relationship.

In this paper, we also provide an illustration of our technique by applying it to the ITeS / Helpdesk service. This technique is however generic enough to be applied to any service vertical. Section II details the related work in value cocreation. We describe our technique in section III and illustrate it with our prototype study in section IV. We conclude in section $\mathrm{V}$ with our ongoing work.

\section{RELATED WORK}

The existence of tangible relationships between business organizations has been observed in a range of studies over the past two decades [1]. The research on relationship marketing argues that instead of a transactional view based on marketingmix, dyadic relationships between business buyers and sellers (B2B) are important in explaining the service outcomes [2]. Another stream of literature discusses theories and models in outsourcing relationships from the Information Systems (IS) discipline. This again emphasizes the notion of partnership and 
integrates power political, social exchange theories to understand the drivers for outsourcing success [3]. Finally, the inter-disciplinary stream of service science [4] literature focusing on Service Dominant (S-D) logic [5] conceptualizes relationship as nested within networks of relationships and occurring between networks of relationships. These networks are not static entities but rather dynamic systems, which work together to achieve mutual benefit (value co-creation) through service provision [6]. Co-creation is the result of a positive sum relationship between two or more businesses, which collectively create value by providing access and transparency of information, engaging in dialogue, and sharing of risks [7].

In B2B IT outsourcing relations service providers (supplier) need to demonstrate value to their clientele on a continuous basis to retain client loyalty. Supplier's existing organizational capabilities as recognized in the resource-based theory of the firm form the basis on which all the current and future value activities of a firm must rely [11]. However, supplier can only facilitate value creation, create the resources or means to enable clients to create value or realize value [8]. It means the client's capabilities are equally important for value creation in $\mathrm{B} 2 \mathrm{~B}$ relations. In most cases value is co-created by both players though collaborative process. This involves access to mutual resources and capabilities as well as the coordination of activities [16].

In many $\mathrm{B} 2 \mathrm{~B}$ relationships value co-creation may be created as one time initiative based on short term business benefits to one or both players. But the challenge is to make value co-creation as a strategic intent. According to Porter's [17] theory on strategy and strategic positioning, striving for operational efficiency does not suffice in the highly competitive global market. Operational efficiency is something that every company can achieve and duplicate and thus does not serve as a basis for building competitive advantage. Companies need to find strategies that give them long-term competitive advantage. Value co-creation is one such initiative. While supplier will be the lead player in this game of value cocreation and will want to exploit the opportunity. The real challenge is to convince clients to actively participate. If a firm is looking for innovation effects, inter-firm relationships are, from this point of view, more effective than the development of internal activities and capabilities, performed with a firm's idiosyncratic framing [12].

\section{A. Maintaining the Integrity of the Specifications}

The template is used to format your paper and style the text. All margins, column widths, line spaces, and text fonts are prescribed; please do not alter them. You may note peculiarities. For example, the head margin in this template measures proportionately more than is customary. This measurement and others are deliberate, using specifications that anticipate your paper as one part of the entire proceedings, and not as an independent document. Please do not revise any of the current designations.

\section{PROPOSED TECHNIQUE}

To compute the value co-creation opportunity, we begin by defining and documenting the value metrics from both supplier and client point of view. An offering may actually provide superior value - but if the supplier doesn't demonstrate and document that claim, a customer manager will likely dismiss it as a marketing puffery. Customer managers, increasingly held accountable for reducing costs, don't have the luxury of simply believing suppliers' assertions [18]. Groonos [8] defines value facilitation, value co-creation, and sole value creation (or value realization) as the three main phases in the value generating process. Based on this we propose Supplier Capability, Strategic Alignment and Client Capability as the criteria for value co-creation in B2B services. We next identify all the input metrics that are tracked to manage the service contract in IT outsourcing.

It is useful to describe value production though a continuum expressing simultaneously the level of complexity involved and the time horizon of value realization, value spectrum [11]. Based on this concept we defined value outcome in B2B services as Transactional Value (lower end), Business (contract) value (middle), and Strategic value (higher end). Transactional value is achieved by improving upon processes involved in day-to-day functioning of the contract, for instance improving upon the system performance or response time. Business value is influenced by long term factors involved in the duration of the relationship, for instance cost savings, ROI etc. Strategic value is attained by taking the relationship to the next level, for instance the scope of the service provider's role is increased when the contract is renewed.

We build a hierarchy of the input metrics to identify the value drivers. The value drivers are classified under each value criteria. The criteria for value and drivers are prioritized on their level of importance. One can use any of the Multi Criteria Decision Analysis (MCDA) tools that are available. For our study, we applied the Analytic Hierarchy Process (AHP) proposed by Saaty [9]. We next map the drivers to the (outcome) value measures and estimate the expected value outcome by adding the overall priority of the value drivers. We derived the expected value measures for the suppliers and client separately. The expectation gap is the difference between the priorities allocated by the client and those allocated by the suppliers. Next we assess the current practices of value drivers and estimate the practiced value measures. This can be done by surveying the current setup or by mining historic data maintained for the service. Opportunity to co-create value is the difference between the value measures expected by the stakeholders and value measures that are in actual practice. If this value is positive, then opportunity exists for value cocreation. On the other hand, if the difference is negative, the relationship is already in a mature state and co-creating value.

The basic assumption of our work is that, organizational priorities (both client and supplier) for value drivers influence the outcome value. We have defined value outcomes in line with value spectrum stated in [11]. Transactional value, Business Value and Strategic value are the objectives for the value co-creation process. Due to the multiple objective nature of the problem, we have used the AHP [9] methodology for decision making process. AHP is designed for situations in which ideas, feelings and emotions affecting the decision process are quantified to provide a numeric scale for 
prioritizing the alternatives. We have used the concept of priorities driven actions of both client and supplier organization for value co-creation. While priorities are driven by strategies they are highly influenced by feelings and emotions and AHP could be an appropriate methodology to assess relative importance of drivers using multi-criteria decision making tool for value co-creation.

Also, we have proposed the hierarchy for value co-creation, which includes the criteria for value co-creation, respective drivers and practices that influence the value outcome. AHP methodology facilitates formalization of subjective decision process owing to the hierarchy structure. Through clear understanding of the problem through dividing in to subproblems, it ensures consistency of decision judgment. Comparison may be made by team involved in process and sensitivity analysis may be performed before final decision [20]. For pair-wise comparison in AHP a survey methodology is illustrated in [15].

\section{EXAMPle: VAlue Co-CREATION In HeLPdesK SERVICE}

For our pilot study, we concentrated on the IT Helpdesk service provided by IBM, India to its clients in the telecommunication domain. We detail the steps that we took to identify the value co-creation opportunity in these contracts.

Step 1: We began by determining the value measures for our study. We compiled a list of value measures tracked by IBM, and the industry specifically in the Helpdesk domain. As explained in section III above, we defined value outcome for Helpdesk services as Transactional Value, Business value, and Strategic value.

Step 2: We defined the value criteria based on value cocreation definition and through interviews conducted with IBM teams providing services and project management teams from client organizations. As stated above, for a Helpdesk service, the value criteria were identified as Client Capability, Supplier Capability and Strategic Alignment.

Step 3: To identify the metrics that can be applied for value creation, we compiled a list of over 150 metrics tracked by IBM and the industry. We considered only those metrics that track value to the organization. We grouped the 150 metrics into 40 groups based on the functions they tracked. These were identified by us as the second factor metrics or practices in the relationship. We next built a hierarchy of the input metrics by further grouping the 40 second factors into 13 groups based on the value they tracked. These 13 groups were identified by us as value drivers. We classified the value drivers under each value criteria defined in step 2 above. Table I lists the classification of value criteria and value drivers. Tables II, III and IV list the practices for the value drivers.

TABLE I. MAPPING THE VALUE DRIVERS TO VALUE CRITERIA

\begin{tabular}{|l|l|}
\hline \multicolumn{1}{|c|}{ Value Criteria } & \multicolumn{1}{c|}{ Value drivers } \\
\hline \multirow{3}{*}{ Strategic Alignment } & Partnership, \\
& Knowledge Management, \\
& $\begin{array}{l}\text { Flexibility, } \\
\text { Communication, }\end{array}$ \\
\hline
\end{tabular}

\begin{tabular}{|l|l|}
\hline & Financial Management \\
\hline Client Capability & Client organization's proficiency, \\
& Self-service, \\
& IT systems and security of client, \\
& Employee proficiency, \\
\hline Supplier (Service Provider) & Agent proficiency, \\
Capability & Supplier organization's proficiency, \\
& Supplier's IT environment, \\
& Service Quality (Solution Accuracy for \\
& Helpdesk service) \\
\hline
\end{tabular}

TABLE II. VALUE DRIVERS AND PRACtices FOR STRATEGIC ALIGNMENT.

\begin{tabular}{|l|l|}
\hline \multicolumn{1}{|c|}{ Value driver } & \multicolumn{1}{c|}{ Includes practices like } \\
\hline Partnership & $\begin{array}{l}\text { Risk/Reward Sharing, } \\
\text { Strategic Direction \& Intent, } \\
\text { Trust and Integrity }\end{array}$ \\
\hline $\begin{array}{l}\text { Knowledge } \\
\text { Management }\end{array}$ & $\begin{array}{l}\text { Innovation, } \\
\text { Cross learning environment, } \\
\text { Structured KM process and tools }\end{array}$ \\
\hline Flexibility/agility & $\begin{array}{l}\text { Receptiveness to Ideas, } \\
\text { Designing Customized Solutions, Deploying } \\
\text { Open source applications. }\end{array}$ \\
\hline Communication & $\begin{array}{l}\text { Inter-office Communication, Management } \\
\text { Outlook sharing, } \\
\text { Reports/ Dashboards }\end{array}$ \\
\hline $\begin{array}{l}\text { Financial } \\
\text { management }\end{array}$ & $\begin{array}{l}\text { Contract Management, } \\
\text { Employee/Labor cost, } \\
\text { Equipment/Assets cost }\end{array}$ \\
\hline
\end{tabular}

TABLE III. VALUE DRIVERS AND PRACTICES FOR CLIENT CAPABILITY

\begin{tabular}{|l|l|}
\hline \multicolumn{1}{|c|}{ Value driver } & \multicolumn{1}{c|}{ Includes practices like } \\
\hline $\begin{array}{l}\text { Organizational } \\
\text { Proficiency or } \\
\text { competency }\end{array}$ & $\begin{array}{l}\text { Global exposure, } \\
\text { Market penetration, } \\
\text { Defined Goals and Objectives, } \\
\text { Reusability of resources }\end{array}$ \\
\hline $\begin{array}{l}\text { Employee Proficiency or } \\
\text { competency }\end{array}$ & $\begin{array}{l}\text { Client's Learning Curve, } \\
\text { Flexible Hours, } \\
\text { Employee Empowerment }\end{array}$ \\
\hline $\begin{array}{l}\text { IT System and Security in } \\
\text { the Client's organization. }\end{array}$ & $\begin{array}{l}\text { State of Art Technology, } \\
\text { Data Management and leakage prevention, } \\
\text { Integration with external systems }\end{array}$ \\
\hline Self Service & $\begin{array}{l}\text { Ease of Use of the self service application, } \\
\text { Remote access capability. }\end{array}$ \\
\hline
\end{tabular}

TABLE IV. VALUE DRIVERS AND PRACTICES FOR SUPPLIER CAPABILITY

\begin{tabular}{|l|l|}
\hline Value driver & Includes practices like \\
\hline $\begin{array}{l}\text { Supplier Organizational } \\
\text { Proficiency or } \\
\text { competency }\end{array}$ & $\begin{array}{l}\text { Experts in Domain/Technology, Global } \\
\text { exposure, } \\
\text { Market penetration, } \\
\text { Headcount productivity, attrition, Efficient } \\
\text { Resource Management }\end{array}$ \\
\hline $\begin{array}{l}\text { Agent Proficiency or } \\
\text { competency }\end{array}$ & $\begin{array}{l}\text { Domain Expertise, } \\
\text { Service Level Agreement Attainment, } \\
\text { Flexible Hours. }\end{array}$ \\
\hline IT System and Security & $\begin{array}{l}\text { State of Art Technology, } \\
\text { Availability/Uptime, } \\
\text { Integration with external systems }\end{array}$ \\
\hline $\begin{array}{l}\text { Service Quality } \\
\text { (solution accuracy for } \\
\text { Helpdesk service) }\end{array}$ & $\begin{array}{l}\text { Reliability of predefined solutions (or } \\
\text { knowledge bases), Service Levels , } \\
\text { Resolution excellence }\end{array}$ \\
\hline
\end{tabular}

Step 4: To prioritize the value criteria and drivers on their level of importance, we created simple questionnaires using Microsoft Excel spreadsheets. We requested various supplier teams in IBM and their corresponding clients to fill out the 
questionnaire and prioritize the drivers based on their professional experience. Figure 7 illustrates the survey questionnaire for prioritizing the expectations of the value criteria. Figure 8 and figure 9 are images of the survey questionnaire we created for determining and prioritizing the actual practices in the supplier and client organization. We took the average ranking of all the responses by service providers and their clients and applying the techniques of AHP (described in section III) identified the priority of the drivers.

Step 5: We mapped the value drivers with the outcome metrics based on the input metrics of the driver and it is listed in Table $\mathrm{V}$ below. We calculated the overall weightage given to each value outcome by the supplier and client. Figure 1 illustrates the AHP tree that we created to calculate the outcome measures expected by the supplier. Table VI illustrates the value of the outcome measures expected by the Supplier. The supplier expects that Strategic value will be the key outcome of their relationship with the client. Figure 2 illustrates the AHP tree that we created to calculate the outcome measures expected by the client. Table VII lists the calculation of these expected value measures. The client expects Business value will be the key outcome of their relationship.

TABLE V. MAPPING THE VALUE DRIVERS TO VALUE MEASURES

\begin{tabular}{|l|l|}
\hline \multicolumn{1}{|c|}{$\begin{array}{c}\text { Value } \\
\text { Measures }\end{array}$} & \multicolumn{1}{c|}{ Value drivers } \\
\hline Strategic & $\begin{array}{l}\text { Partnership, flexibility, communication, supplier org. } \\
\text { proficiency, client org. proficiency, IT systems and } \\
\text { security of client }\end{array}$ \\
\hline Business & $\begin{array}{l}\text { Communication, Financial Management, Self-service, } \\
\text { client org. proficiency, and all drivers of Supplier } \\
\text { Capability }\end{array}$ \\
\hline Transactional & $\begin{array}{l}\text { Knowledge Management, Employee proficiency, } \\
\text { Communication, Agent proficiency, Client's IT System } \\
\text { and Security, Supplier's IT environment, Service } \\
\text { Quality }\end{array}$ \\
\hline
\end{tabular}

From the two results, it is obvious that there is an expectation gap between what value the supplier and the client want from their relationship. Figure 3 illustrates this expectation gap.

TABLE VI. OVERALL PRIORITY OF THE VALUE DRIVERS ACCORDING TO THE SUPPLIER

\begin{tabular}{|l|l|}
\hline \multicolumn{1}{|c|}{ Value Measure } & \multicolumn{1}{c|}{ Supplier Ranking } \\
\hline Strategic & $\begin{array}{c}.418 * .71+0.113^{*} .71+0.092^{*} .71 \\
\end{array}$ \\
& $+.368 * .125+.294 * .125+.245^{*} .161=0.564$ \\
\hline Business & $0.092 * .71+0.103 * .71+.185 * .125+.368^{*} .125+$ \\
& $.161=0.368$ \\
\hline Transactional & $.274 * .71+.092 * .71+.153 * .125+.294 * .125+.271 * .16$ \\
& $1+.159 * .161+.325 * .161=0.437$ \\
\hline
\end{tabular}

TABLE VII. OVERALL PRIORITY OF THE VALUE MEASURES ACCORDING TO THE CLIENT

\begin{tabular}{|l|c|}
\hline Value Measure & Supplier Ranking \\
\hline Strategic & $.29 * .33+0.36 * .33+0.07 * .33+.5 * .21+.23 * .21$ \\
\hline
\end{tabular}

\begin{tabular}{|l|l|}
\hline & $+.51 * .46=0.625$ \\
\hline Business & $0.07 * .33+0.14 * .33+.06 * .21+.5 * .21+.46=0.646$ \\
\hline Transactional & $.14 * .33+.07 * .33+.21 * .21+.23 * .21+.14 * .46+$ \\
& $.23 * .46+.12 * .46=0.387$ \\
\hline
\end{tabular}

Step 6: Assess the current practices of value drivers and estimate practiced value measures

We surveyed the clients and suppliers to determine which value drivers were being currently practiced in the relationship. The survey assigned value 0 to a driver which was not practiced and 1 to a driver that was practiced in the relationship. Since the organization didn't have any priorities in practice, equal weightage were allocated to all drivers.

Figure 4 illustrates the practiced value drivers and the ranking for the practiced value measured based on current practices in the contract. Table VIII lists the calculations of the practiced priorities for the various value measures.

We measured the overall priority of the value drivers by multiplying its priority with the priority of its parent value criteria.

TABLE VIII. PRACTICED PRIORITY OF THE VALUE MEASURES

\begin{tabular}{|l|c|}
\hline \multicolumn{1}{|c|}{ Value Measure } & Supplier Ranking \\
\hline Strategic & $.33 * .20+.33 * .25+.33 * .25+.33 * .25=0.313$ \\
\hline Business & $0.33 * .20+.33 * .25+.33 * .75=0.396$ \\
\hline Transactional & $.33 * .25+.33 * .25+.33 * .25=0.231$ \\
\hline
\end{tabular}

Steps 7: Opportunity to co-create value can be measured as the difference between the Expected value measures and the Practiced or Observed value measures. Table IX lists the value co-creation opportunity that exists for our Helpdesk study. Once we have identified the value criterion that presents the most opportunity of value, we identify the value drivers that will influence this value. Figure 5 illustrates the opportunity from the client's perspective and figure 6 illustrates the opportunity for value creation from the supplier's perspective. In the figures the drivers colored in red are the ones where the most opportunity for value co-creation exists. In this example the opportunity is in "strategic value" for both client and service provider. Hence, both of them can co-create "strategic value" through collaborative strategies and efforts on the related drivers.

TABLE IX. VALUE CO-CREATION OPPORTUNITY

\begin{tabular}{|l|l|l|}
\hline Value Measure & $\begin{array}{l}\text { Opportunity per } \\
\text { Client's expectation }\end{array}$ & $\begin{array}{l}\text { Opportunity per } \\
\text { Supplier's expectation }\end{array}$ \\
\hline Strategic & $\mathbf{0 . 3 1 2}$ & $\mathbf{0 . 2 5 1}$ \\
\hline Business & 0.25 & $\sim 0$ \\
\hline Transactional & 0.156 & 0.2 \\
\hline
\end{tabular}




\section{CONCLUSION AND ON GOING WORK}

The seven step process that we have developed helps to identify value creation opportunity for service provider (supplier) and the client. Once both players have identified the value creation opportunity, then we can determine the cocreation opportunity from the common expectations. As illustrated in section IV, both the service provider and the client identified strategic value as the common measure that they can co-create. In case there is no common opportunity then it indicates that there is a mismatch in the priorities of the two parties. In such a scenario the gap in the priorities should be resolved before any value co-creation steps can be initiated.

As part of our ongoing work, we have also applied this technique on three other B2B accounts in IBM. One of the challenges we faced was in getting the client organizations to participate in this study since they perceived it would need significant effort on their part. However, initial workshops and one-on-one sessions that we have conducted for this technique have received positive feedback. Both the service providers as well as service clients are now excited to participate in these value co-creation workshops. We continue to analyze the results of the survey and provide feedback to the stakeholders on improving their relationship by concentrating on the value drivers that will provide the most opportunity in value cocreation. Our future plan is to apply this technique on many B2B contracts so as to get a baseline measure for the priorities for value criteria and value drivers which can then be used as a benchmark by service providers while identifying value cocreation opportunities.

As part of our ongoing work, we are also calculating the practiced priorities for drivers with defined weightage. In addition to surveys, we also plan to data mine the helpdesk data maintained by the service providers by using a data mining tool. Association rules that will be generated by the tool can be used to determine the importance given to a metric in the existing relationship. This will help determine weightage given to the value drivers in practice.

We also propose to introduce collective action non-zero sum game theory to influence both service provider and client to participate in the value co-creation initiative.

\section{ACKNOWLEDGMENT}

The authors would like to thank Mr. Shashwat Sharma who developed the survey questionnaires and helped us analyze the survey results. Authors also wish to thank the GTS group in IBM for participating in the pilot for this technique and helping us refine it.

\section{REFERENCES}

[1] Håkansson,H., and Ford, D., "How should companies interact in business networks?", Journal of Business Research 55(2), pp. 133-139, 2002

[2] Möller, K, and Halinen, A. "Relationship Marketing Theory: Its Roots and Direction", Journal of Marketing Management (16), February 2000, pp. 29-54.

[3] Lee, J.N, and Kim, Y.G. "Effect of partnership quality on IS outsourcing success: conceptual framework and empirical validation", Journal of Management Information Systems (15:4), March 1999, pp. 29-61.

[4] Spohrer, J., Vargo, S.L., Caswell, N., and Maglio, P. P. "The Service System is the Basic Abstraction of Service Science," Proceedings of HICSS-41, The 41st Hawaii International Conference on System Sciences, 2008.

[5] Vargo, S.L, and Lusch, R.F. "Evolving to a New Dominant Logic for Marketing", Journal of Marketing (68:1),January 2004, pp. 29-54.

[6] Vargo, S.L "Toward a transcending conceptualization of relationship: a service-dominant logic perspective", Journal of Business \& Industrial Marketing (24:5/6), 2009, pp. 373-379.

[7] Prahalad, C.K., Ramaswamy V., "Co-creating unique value with clients", Strategy \& Leadership, 2004, Vol. 32 Iss: 3, pp.4 - 9

[8] Grönroos, C., "Adopting a service business logic in relational businessto-business marketing: value creation, interaction and joint value cocreation". Otago Forum 2 (2008) - Academic Papers

[9] Saaty, T.L., "How to make a decision: The analytic hierarchy process", European Journal of Operational Research, Volume 48, Issue 1, 5 September 1990, pp. 9-26

[10] ICL Ng, et. al., "Value co-creation in the delivery of outcome-based contracts for business-to-business service", 2009.

[11] Moller, K, Torronen P, Business supplier's value creation potential: Acapability-based analysis. Industrial Marketing Management, 2003, 32(2), pp. 109-118.

[12] Catarina Roseira, Carlos Brito, "Value Co-creation with Suppliers", FEP Working paper, Nov. 2009.

[13] Rajamani N., Mani, D., Mehta, S., Chebiyyam, M., "Quality, Satisfaction and Value in Outsourcing: Role of Relationship Dynamics and Proactive Management", International Conference on Information Systems, 2010

[14] Ordanini, Andrea and Pasini, P. "Service Co-Production and Value Cocreation: The Case for a Service-Oriented Architecture," European Management Journal, 26 (5), 289-297, 2008.

[15] Bhagwat. R, Sharma.M.K, "Performance measurement of supply chain management using the analytical hierarchy process", Production Planning \& Control, December 2007, Vol.18, No.8, pp 666-680.

[16] Mele, C. " Managing value creation within a project: From value delivery sequence to value co-creating network", 37th EMAC conference, University of Brighton, 2008

[17] Porter M.E. " Competitive advantage" . Free press, New York, 1985

[18] Anderson, J. et, al. "Customer Value Propositions in Business Markets", Harvard Business Review, March, 2006

[19] Stalk G., Evans, P. and Shulman, L., 1992, Competing on capabilities: the new rules of corporate strategy. Harvard Business Review, MarchApril, pp. 57-69.

[20] Abdul- Hamid, Y.T., “ The analytical hierarchy process approach to the choice off manufacturing plant layout', Proc. Inst. Mech. Eng., Part B, J. Eng. Manuf, 1999, 213 (B4), pp. 397-406 


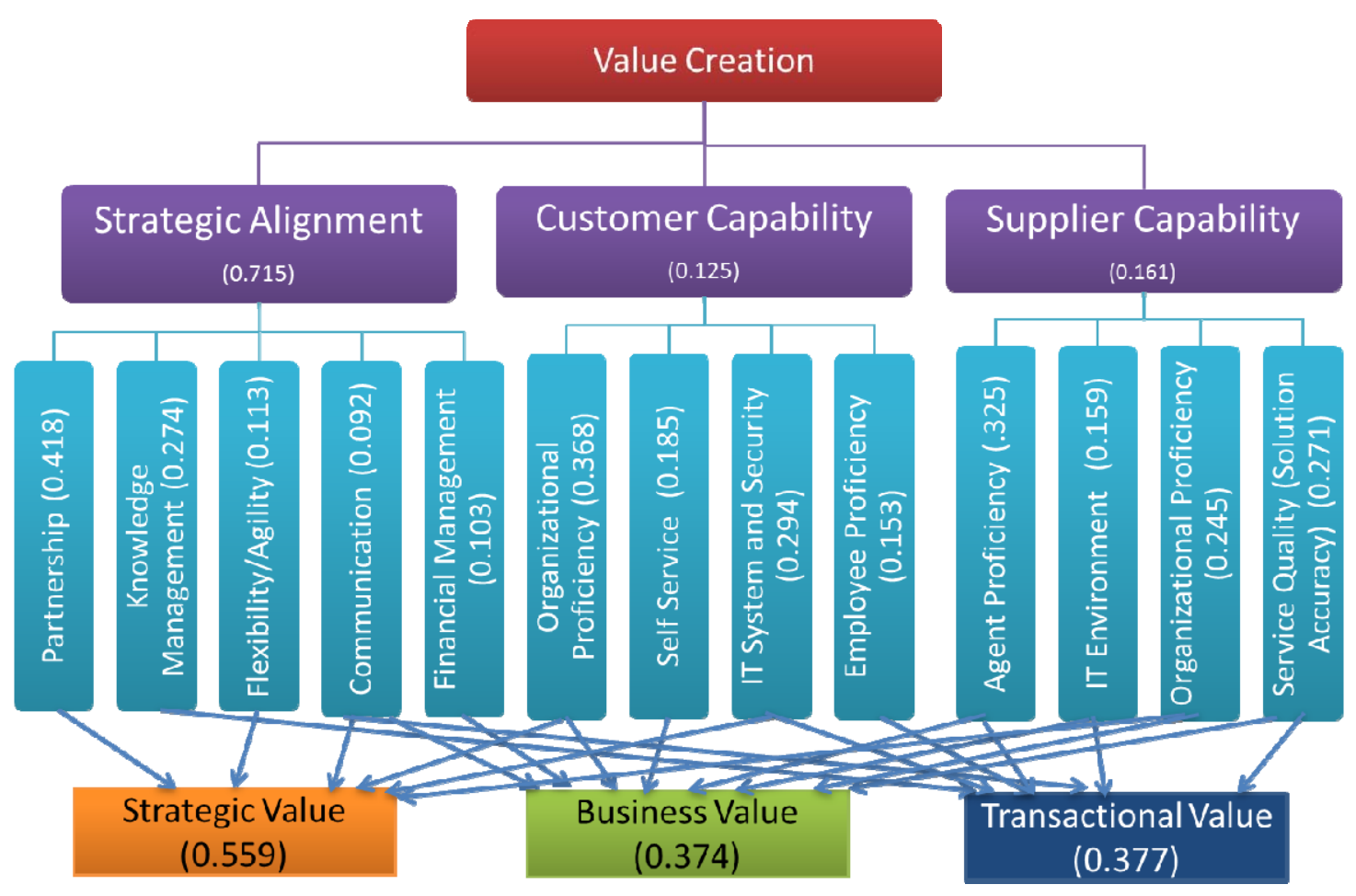

Figure 1. Expected value co-creation (supplier) measured using AHP.

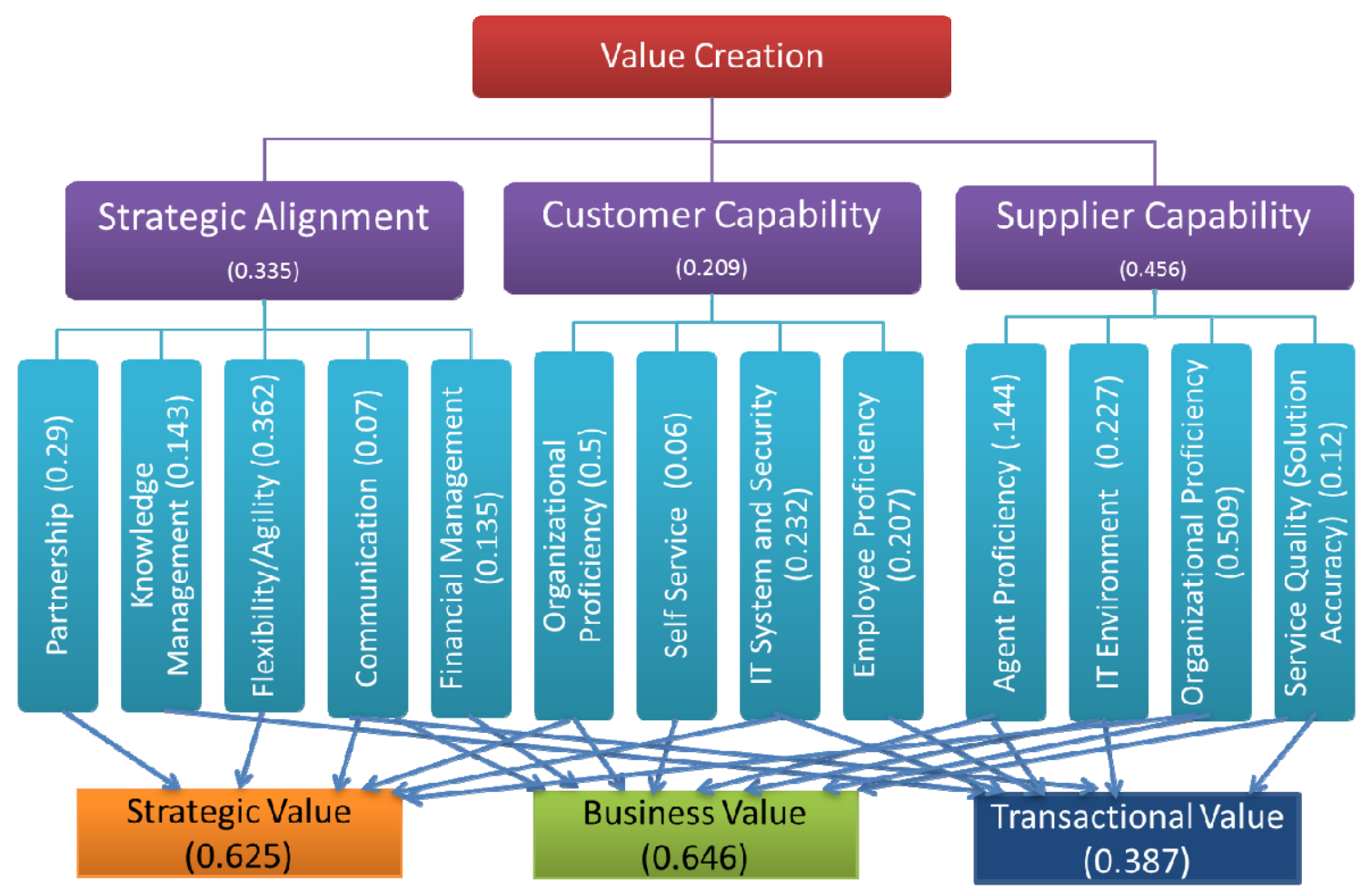

Figure 2. Expected value co-creation (client) measured using AHP. 


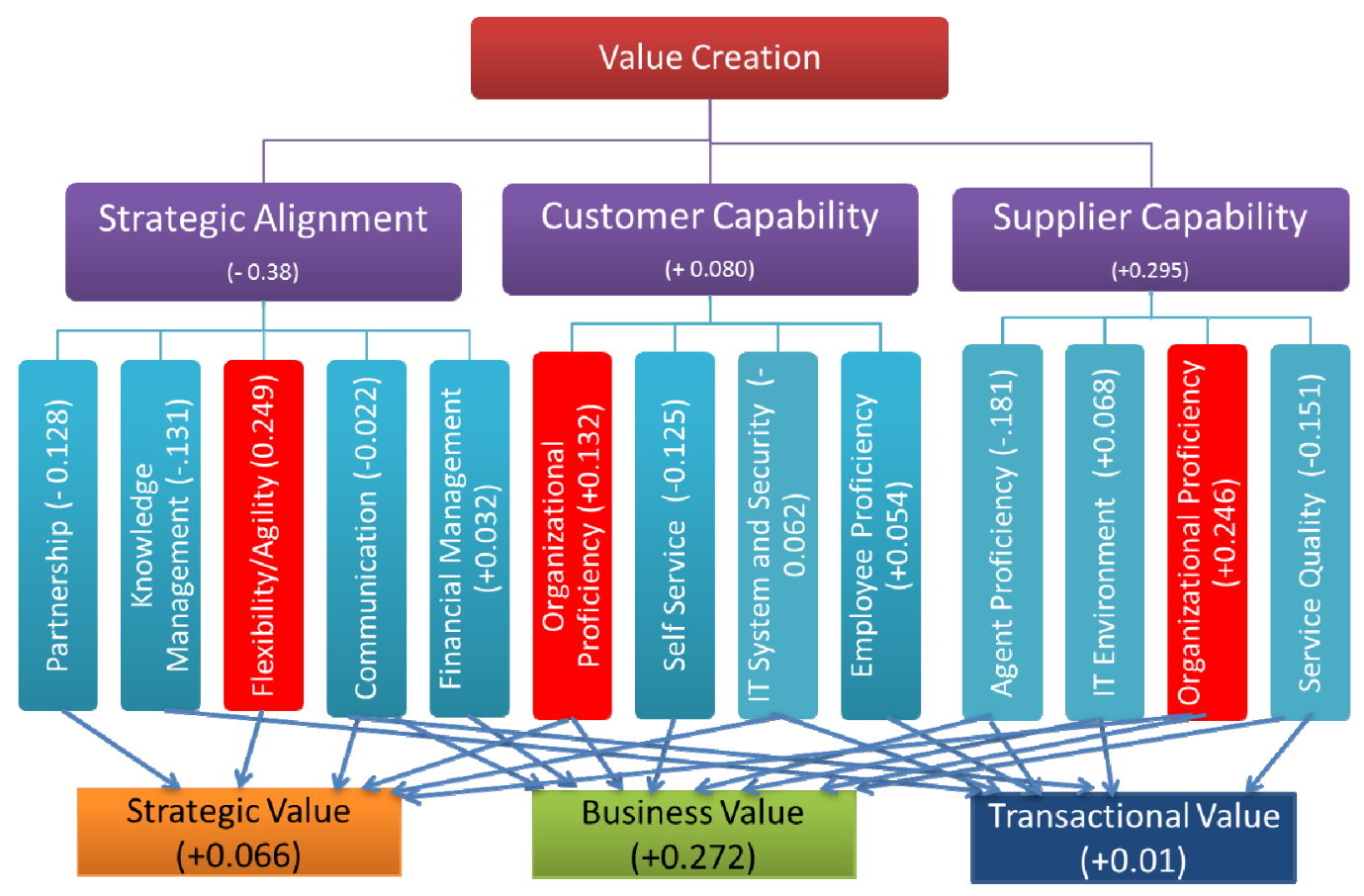

Figure 3. Expectation gap

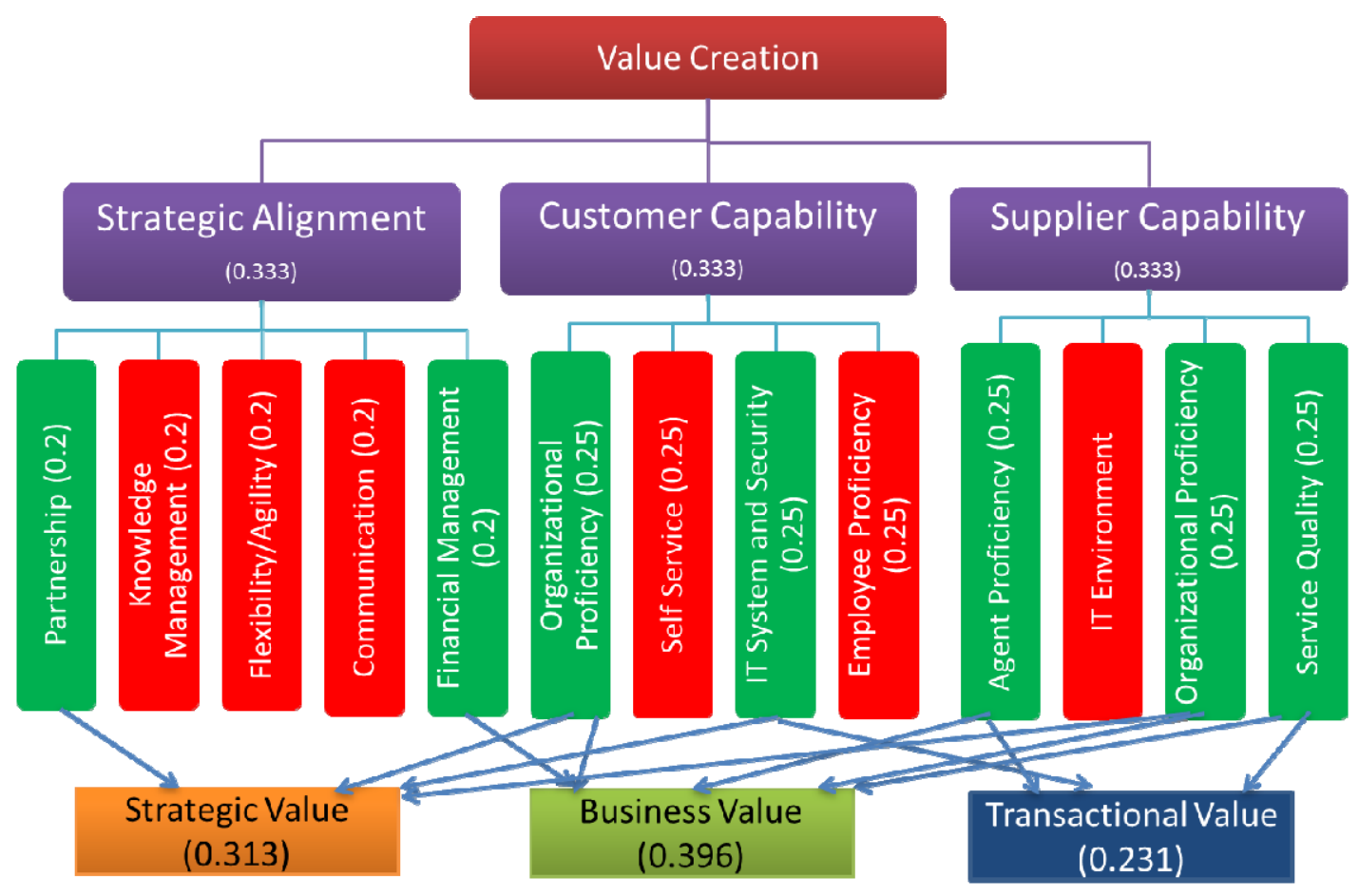

Figure 4. Practised Value 


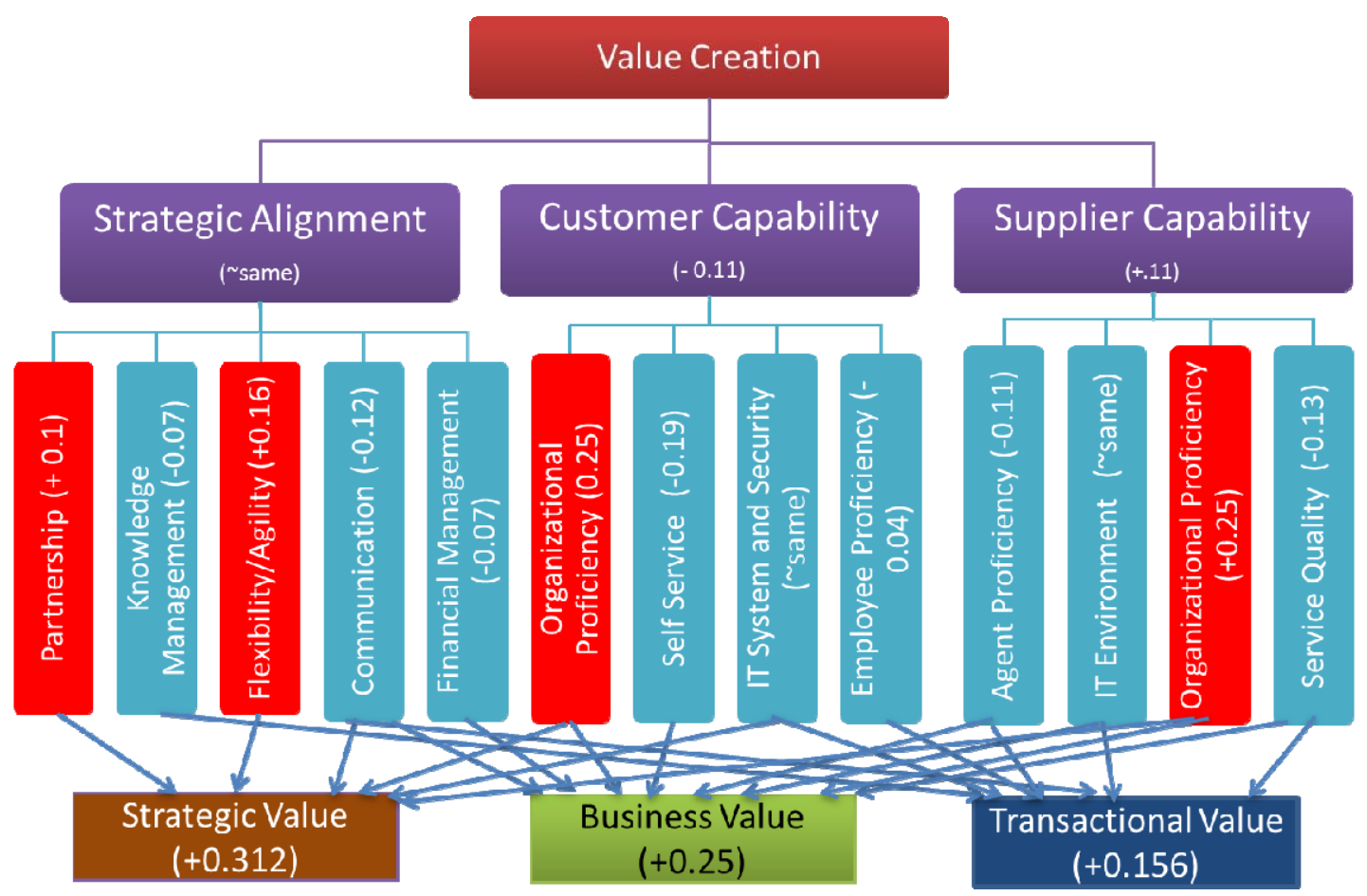

Figure 5. Value creation opportunity from client's perspective

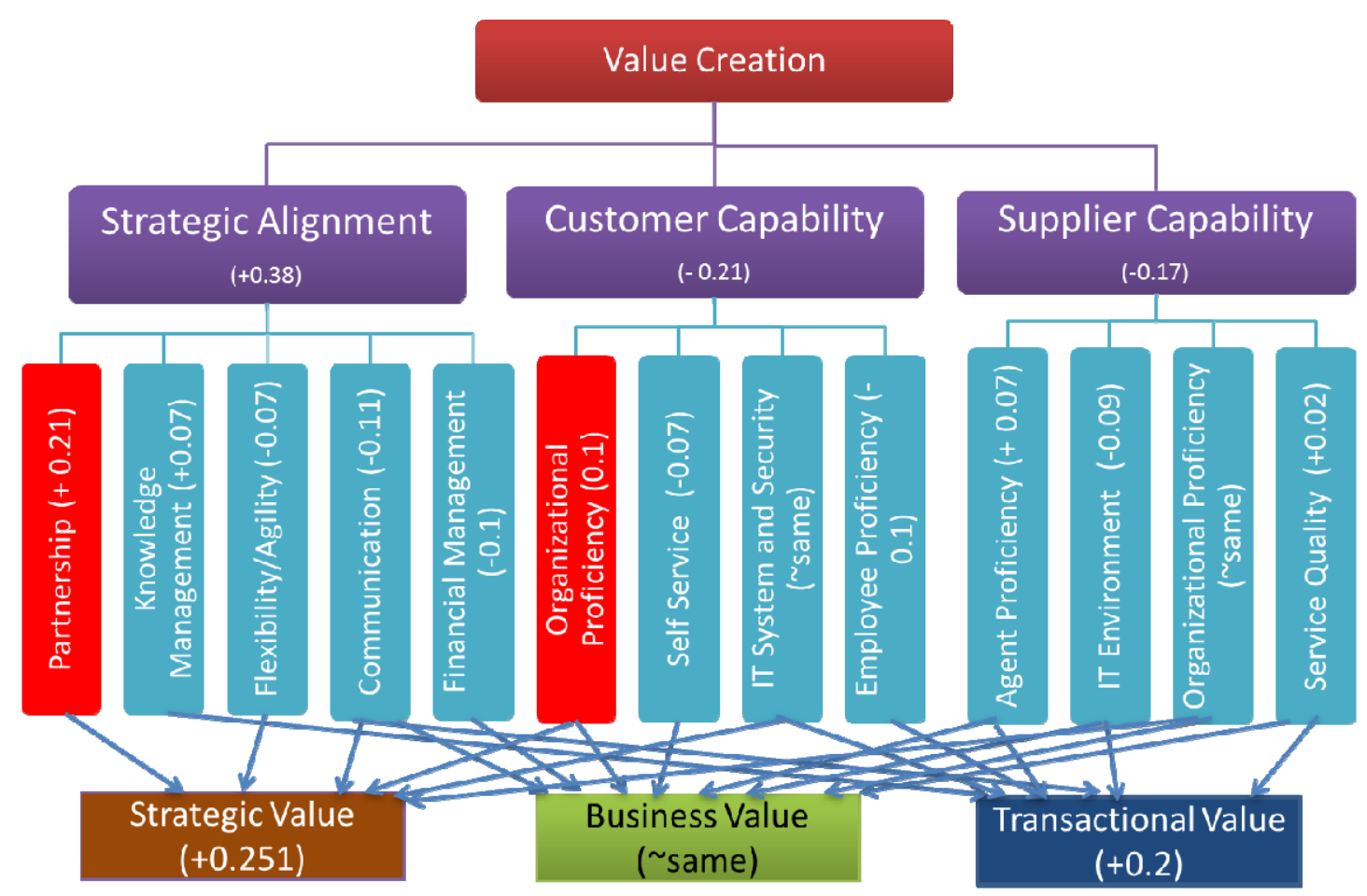

Figure 6. Value creation opportunity from Supplier's perspective 


\begin{tabular}{|c|c|c|c|c|c|c|c|c|c|c|c|}
\hline \multirow[b]{2}{*}{ Category } & \multirow[b]{2}{*}{ Criterion A } & \multicolumn{9}{|c|}{ Relative level of importance (Select one) ${ }^{*}$} & \multirow[b]{2}{*}{ Criterion B } \\
\hline & & \begin{tabular}{|c|} 
Extreme \\
Importance \\
\end{tabular} & \begin{tabular}{|l|} 
Very Strong \\
Importance \\
\end{tabular} & \begin{tabular}{|c|} 
Strong \\
Importance
\end{tabular} & \begin{tabular}{|c|} 
Moderate \\
Importance \\
\end{tabular} & \begin{tabular}{|c|} 
Equal \\
Importance
\end{tabular} & \begin{tabular}{|c|} 
Moderate \\
Importance \\
\end{tabular} & \begin{tabular}{|c|} 
Strong \\
Importance
\end{tabular} & \begin{tabular}{|c|} 
Very Strong \\
Importance \\
\end{tabular} & \begin{tabular}{|c|} 
Extreme \\
Importance
\end{tabular} & \\
\hline \multirow{3}{*}{$\begin{array}{c}\text { Criteria for } \\
\text { Co-creation } \\
\text { of a Value }\end{array}$} & \begin{tabular}{|l|} 
Client \\
Capability
\end{tabular} & $c$ & $c$ & o & 0 & c. & 0 & 0 & o & $c$ & $\begin{array}{l}\text { Supplier } \\
\text { Capability }\end{array}$ \\
\hline & \begin{tabular}{|l|} 
Strategic \\
Alignment
\end{tabular} & $\mathrm{c}$ & 0 & 0 & $c$ & • & 0 & $c$ & 0 & 0 & \begin{tabular}{|l|} 
Client \\
Capability
\end{tabular} \\
\hline & \begin{tabular}{|l|} 
Strategic \\
Alignment
\end{tabular} & 0 & 0 & 0 & 0 & • & 0 & 0 & 0 & 0 & \begin{tabular}{|l|} 
Supplier \\
Capability
\end{tabular} \\
\hline \multirow{10}{*}{$\begin{array}{l}\text { Drivers for } \\
\text { Strategic } \\
\text { Alignment* }\end{array}$} & Partnership & 0 & 0 & 0 & 0 & c & 0 & 0 & 0 & 0 & \begin{tabular}{|l} 
Knowledge \\
Management
\end{tabular} \\
\hline & Partnership & 0 & 0 & 0 & 0 & • & 0 & 0 & 0 & 0 & $\begin{array}{l}\text { Flexibility/Agility } \\
\text { in the relationship }\end{array}$ \\
\hline & Partnership & 0 & $c$ & c & $c$ & ( & 0 & 0 & 0 & 0 & Communication \\
\hline & Partnership & 0 & 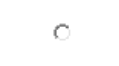 & $\mathrm{c}$ & 0 & c & 0 & 0 & 0 & 0 & $\begin{array}{l}\text { Cost/Budget } \\
\text { Management }\end{array}$ \\
\hline & \begin{tabular}{|l|} 
Knowledge \\
Management
\end{tabular} & 0 & 0 & 0 & 0 & $\bullet$ & 0 & 0 & 0 & 0 & $\begin{array}{l}\text { Flexibility/Agility } \\
\text { in the relationship }\end{array}$ \\
\hline & $\begin{array}{l}\text { Knowledge } \\
\text { Management }\end{array}$ & 0 & 0 & 0 & 0 & c & 0 & 0 & 0 & 0 & Communication \\
\hline & \begin{tabular}{|l|} 
Knowledge \\
Management
\end{tabular} & 0 & 0 & c & 0 & c & $c$ & $c$ & 0 & 0 & $\begin{array}{l}\text { Cost/Budget } \\
\text { Management }\end{array}$ \\
\hline & $\begin{array}{l}\text { Flexibility/Agility } \\
\text { in the relationship }\end{array}$ & 0 & 0 & 0 & 0 & $\bullet$ & 0 & 0 & 0 & 0 & Communication \\
\hline & $\begin{array}{l}\text { Flexibility/Agility } \\
\text { in the relationship }\end{array}$ & 0 & 0 & 0 & 0 & 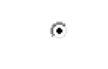 & 0 & 0 & $c$ & 0 & \begin{tabular}{|l|} 
Cost/Budget \\
Management
\end{tabular} \\
\hline & Communication & 0 & 0 & 0 & 0 & c & $c$ & 0 & 0 & 0 & $\begin{array}{l}\text { Cost/Budget } \\
\text { Management }\end{array}$ \\
\hline \multirow{6}{*}{$\begin{array}{c}\text { Drivers for } \\
\text { Client } \\
\text { Capability }\end{array}$} & $\begin{array}{l}\text { Organizational } \\
\text { Proficiency }\end{array}$ & c & 0 & 0 & 0 & c & 0 & 0 & 0 & 0 & \begin{tabular}{|l|} 
Employee \\
Proficiency
\end{tabular} \\
\hline & \begin{tabular}{|l|} 
Organizational \\
Proficiency
\end{tabular} & 0 & 0 & 0 & $c$ & c & 0 & 0 & 0 & 0 & $\begin{array}{l}\text { IT System and } \\
\text { Security }\end{array}$ \\
\hline & \begin{tabular}{|l|} 
Organizational \\
Proficiency
\end{tabular} & 0 & 0 & 0 & 0 & c & 0 & $c$ & 0 & 0 & Self Service \\
\hline & \begin{tabular}{|l|} 
Employee \\
Proficiency
\end{tabular} & 0 & 0 & 0 & 0 & $\odot$ & 0 & 0 & 0 & 0 & $\begin{array}{l}\text { IT System and } \\
\text { Security }\end{array}$ \\
\hline & \begin{tabular}{|l} 
Employee \\
Proficiency
\end{tabular} & 0 & 0 & 0 & 0 & c & 0 & 0 & $c$ & 0 & Self Service \\
\hline & $\begin{array}{l}\text { IT System and } \\
\text { Security }\end{array}$ & 0 & 0 & $c$ & 0 & $\odot$ & $c$ & 0 & o & $c$ & Self Service \\
\hline \multirow{6}{*}{$\begin{array}{l}\text { Drivers for } \\
\text { Supplier } \\
\text { Capability* }\end{array}$} & \begin{tabular}{|l|} 
Supplier \\
Organization
\end{tabular} & 0 & 0 & 0 & 0 & 6 & $c$ & 0 & 0 & 0 & \begin{tabular}{|l|} 
Agent \\
Proficiency
\end{tabular} \\
\hline & \begin{tabular}{|l} 
Supplier \\
Organization
\end{tabular} & 0 & 0 & 0 & 0 & 6 & $c$ & 0 & 0 & 0 & $\begin{array}{l}\text { IT System and } \\
\text { Security }\end{array}$ \\
\hline & \begin{tabular}{|l} 
Supplier \\
Organization
\end{tabular} & $c$ & $c$ & $c$ & $c$ & $\odot$ & $c$ & $c$ & $c$ & $c$ & Service Quality \\
\hline & \begin{tabular}{|l|} 
Agent \\
Proficiency
\end{tabular} & 0 & $c$ & $c$ & $c$ & c & $c$ & 0 & $c$ & 0 & $\begin{array}{l}\text { IT System and } \\
\text { Security }\end{array}$ \\
\hline & \begin{tabular}{|l} 
Agent \\
Proficiency
\end{tabular} & 0 & $c$ & 0 & 0 & c & 0 & 0 & $c$ & 0 & Service Quality \\
\hline & $\begin{array}{l}\text { IT System and } \\
\text { Security }\end{array}$ & 0 & 0 & 0 & 0 & c & 0 & 0 & 0 & 0 & Service Quality \\
\hline \multirow{3}{*}{$\begin{array}{l}\text { Expected } \\
\text { Outcome } \\
\text { from } \\
\text { Relation }\end{array}$} & Strategic Value & c & $c$ & 0 & 0 & 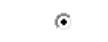 & 0 & $c$ & c & 0 & Business Value \\
\hline & \begin{tabular}{|l} 
Transactional \\
Value
\end{tabular} & c & 0 & 0 & 0 & $\bullet$ & 0 & 0 & 0 & 0 & Strategic Value \\
\hline & $\begin{array}{l}\text { Transactional } \\
\text { Value }\end{array}$ & o & $c$ & $c$ & 0 & c & $c$ & 0 & 0 & 0 & Business Value \\
\hline
\end{tabular}

Figure 7. Survey questionnaire for expected priorities of value drivers 


\begin{tabular}{|c|c|c|c|c|c|c|c|c|c|}
\hline $\begin{array}{l}\text { Value } \\
\text { Criteria }\end{array}$ & $\begin{array}{l}\text { Value } \\
\text { Drivers }\end{array}$ & Second Order Factors (Practices) & $\begin{array}{l}\text { Priority } \\
(\mathrm{H} / \mathrm{M} / \mathrm{L})\end{array}$ & N/A & \begin{tabular}{|l|} 
Strongly \\
Disagree \\
\end{tabular} & Disagree & Neutral & Agree & \begin{tabular}{|c|} 
Strongly \\
Agree
\end{tabular} \\
\hline \multirow{13}{*}{$\begin{array}{c}\text { Supplier } \\
\text { Capability }\end{array}$} & \multirow{3}{*}{$\begin{array}{l}\text { Organizational } \\
\text { Proficiency }\end{array}$} & $\begin{array}{l}\text { The supplier / organization has global exposure and } \\
\text { market penetration in their services domain }\end{array}$ & N/A & $\odot$ & $c$ & $c$ & $c$ & $c$ & $c$ \\
\hline & & $\begin{array}{l}\text { The supplier / organization has expertise in domain, and } \\
\text { best practices }\end{array}$ & N/A & $\odot$ & $c$ & $c$ & 0 & $c$ & 0 \\
\hline & & $\begin{array}{l}\text { The supplier / organization is resilient, and efficiently } \\
\text { manages resources, including infrastructure and personnel }\end{array}$ & N/A & (c) & $c$ & $c$ & 0 & $c$ & 0 \\
\hline & \multirow{4}{*}{$\begin{array}{c}\text { Agent } \\
\text { (Support Team) } \\
\text { Proficiency }\end{array}$} & $\begin{array}{l}\text { The supplier / organization has expertise in the } \\
\text { domain/technology they support }\end{array}$ & N/A & $\odot$ & $c$ & $c$ & $c$ & $c$ & 0 \\
\hline & & $\begin{array}{l}\text { When interacting with personnel from the } \\
\text { customer/company side, the agent feels he/she has } \\
\text { significant autonomy in that interaction }\end{array}$ & N/A & c & $c$ & 0 & $c$ & $c$ & 0 \\
\hline & & $\begin{array}{l}\text { The agent is clear on what the personnel he/she interacts } \\
\text { with on the company/customer side SHOULD DO under the } \\
\text { contract }\end{array}$ & N/A & 6. & $c$ & 0 & 0 & $c$ & c \\
\hline & & $\begin{array}{l}\text { When interacting with personnel from the customer/company } \\
\text { side, the agent feels he/she can do more than what his/her job } \\
\text { specifies to ensure good contract performance }\end{array}$ & N/A & c. & $c$ & $c$ & 0 & $c$ & 0 \\
\hline & \multirow{3}{*}{ IT Environment } & $\begin{array}{l}\text { The supplier / organization has deployed cutting-edge } \\
\text { technology }\end{array}$ & N/A & $\odot$ & $c$ & $c$ & $c$ & $c$ & $c$ \\
\hline & & $\begin{array}{l}\text { The supplier / organization ensures constant availability / } \\
\text { up-time of their IT environment }\end{array}$ & N/A & 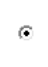 & $c$ & $c$ & 0 & $c$ & $c$ \\
\hline & & $\begin{array}{l}\text { The supplier / organization's IT environment is integrated } \\
\text { with client applications and systems }\end{array}$ & N/A & c. & 0 & 0 & 0 & 0 & 0 \\
\hline & \multirow{3}{*}{ Service Quality } & $\begin{array}{l}\text { The supplier / organization provides service excellence in } \\
\text { line with SLAs }\end{array}$ & N/A & $\odot$ & $c$ & 0 & 0 & 0 & $c$ \\
\hline & & $\begin{array}{l}\text { The supplier / organization provides reliable predefined } \\
\text { solutions (products, apps, knowledge bases etc.) }\end{array}$ & N/A & $\odot$ & $c$ & 0 & 0 & 0 & $c$ \\
\hline & & $\begin{array}{l}\text { The supplier / organization works towards continuous } \\
\text { improvements in the services provided }\end{array}$ & N/A & $\odot$ & 0 & $c$ & 0 & $c$ & $c$ \\
\hline \multirow{12}{*}{$\begin{array}{c}\text { Client } \\
\text { Capability }\end{array}$} & \multirow{3}{*}{$\begin{array}{l}\text { Organizational } \\
\text { Proficiency }\end{array}$} & $\begin{array}{l}\text { The client / organization has global exposure and market } \\
\text { penetration in their services domain }\end{array}$ & N/A & $\odot$ & 0 & 0 & 0 & 0 & 0 \\
\hline & & $\begin{array}{l}\text { The client / organization has clearly defined goals, } \\
\text { objectives and processes }\end{array}$ & N/A & $\odot$ & $c$ & 0 & 0 & c & $c$ \\
\hline & & $\begin{array}{l}\text { The client / organization efficiently manages and re-uses } \\
\text { resources, including infrastructure and personnel }\end{array}$ & N/A & $\odot$ & 0 & 0 & 0 & $c$ & $c$ \\
\hline & \multirow{3}{*}{$\begin{array}{l}\text { Employee } \\
\text { Proficiency }\end{array}$} & $\begin{array}{l}\text { I am clear on what the personnel I interact with on the } \\
\text { company/customer side is doing under the contract }\end{array}$ & N/A & $\odot$ & c & 0 & $\mathrm{c}$ & 0 & $c$ \\
\hline & & \begin{tabular}{|l|} 
When interacting with personnel from the \\
supplier/company side, I feel I (Client) can use my \\
personal judgement to ensure good contract performance
\end{tabular} & N/A & $\odot$ & $c$ & 0 & 0 & 0 & $c$ \\
\hline & & $\begin{array}{l}\text { The client / organization provides adequate training to its } \\
\text { employees on operational and technical skills to use the } \\
\text { services }\end{array}$ & N/A & $\odot$ & $c$ & $c$ & $c$ & $c$ & 0 \\
\hline & \multirow{3}{*}{$\begin{array}{l}\text { IT System } \\
\text { and Security }\end{array}$} & $\begin{array}{l}\text { The client / organization has deployed state-of-the-art } \\
\text { technology }\end{array}$ & N/A & $\odot$ & $c$ & $c$ & $c$ & 0 & 0 \\
\hline & & $\begin{array}{l}\text { The client / organization uses open-source applications for } \\
\text { their IT systems, instead of proprietary IT systems }\end{array}$ & N/A & $\odot$ & $c$ & c & $c$ & o & 0 \\
\hline & & $\begin{array}{l}\text { The client / organization has efficient security policies to } \\
\text { prevent data leakage }\end{array}$ & N/A & $\odot$ & c & 0 & $c$ & $c$ & $c$ \\
\hline & \multirow{3}{*}{ Self Service } & $\begin{array}{l}\text { The client / organization is able to easily use the services } \\
\text { themselves }\end{array}$ & N/A & $\odot$ & $c$ & $c$ & 0 & 0 & 0 \\
\hline & & $\begin{array}{l}\text { The client / organization is able to effectively resolve } \\
\text { issues }\end{array}$ & N/A & $\odot$ & c & c & $c$ & o & o \\
\hline & & $\begin{array}{l}\text { The client / organization is able to provide remote-access } \\
\text { capability to its employees and end-users }\end{array}$ & N/A & $\odot$ & $c$ & 0 & 0 & $c$ & $c$ \\
\hline
\end{tabular}

Figure 8. Questionnaire for practiced value drivers for supplier and client capability 


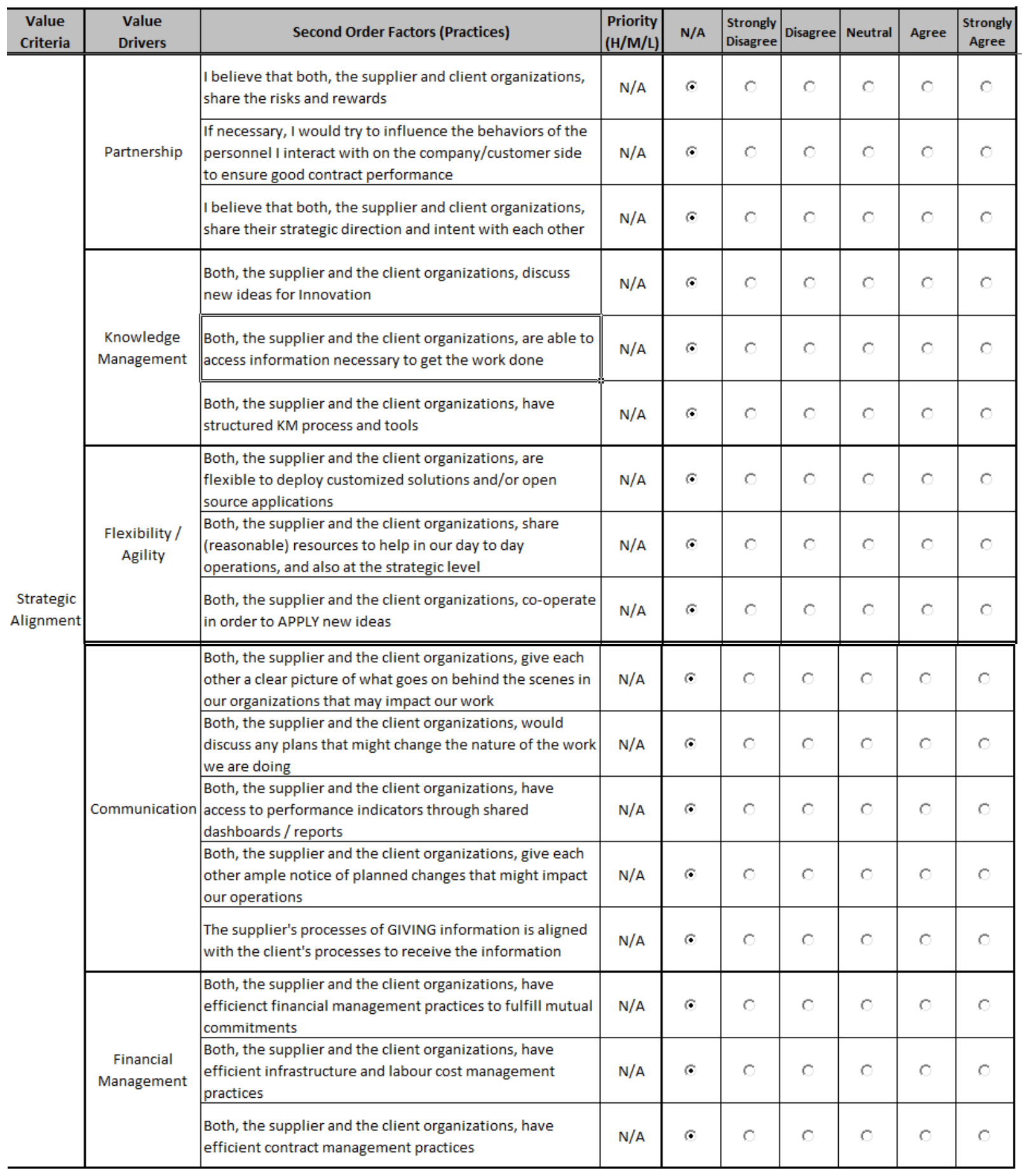

Figure 9. Questionnaire for practised value drivers for Strategic Alignment 